\title{
Drug Repositioning: Concept, Classification, Methodology, and Importance in Rare/Orphans and Neglected Diseases
}

\author{
Emanuel Almeida Moreira de Oliveira ${ }^{1}$, Karen Luise $\operatorname{Lang}^{1,2^{*}}$ \\ ${ }^{1}$ Department of Pharmacy, Federal University of Juiz de Fora - Governador Valadares, MG, Brazil. \\ ${ }^{2}$ Multicenter Program in Biochemistry and Molecular Biology, Federal University of Juiz de Fora - Governador Valadares, MG, Brazil.
}

\begin{tabular}{|c|c|}
\hline ARTICLE INFO & ABSTRACT \\
\hline Article history: & \multirow{5}{*}{$\begin{array}{l}\text { The development of new drugs is a long and complex process, with extremely high investment and small expectation } \\
\text { of success. In recent years, there was a significant decline in the number of new drugs approved for clinical use, } \\
\text { notwithstanding powerful tools were developed to support the research and development (R\&D) process. Drug } \\
\text { Discovery programs are pursuing strategies that optimize the R\&D process. Among them, we highlight the drug } \\
\text { repositioning as an approach that seeks new therapeutic applications for already approved drugs, different from its } \\
\text { initial indication. This strategy is aimed to reduce costs and research time considerably. There is a limited commercial } \\
\text { interest in the development of drugs for the treatment of rare/orphans and neglected diseases, due to the onerous nature, } \\
\text { the associated risk and low return on investments in R\&D. Thus, repositioning is important, due to the advantages } \\
\text { over traditional approaches, to an area that has historically suffered from limited resources and an enormous need for } \\
\text { effective therapies. Herein, this review discussed recent data about drug repositioning as an important strategy for the } \\
\text { development of new therapies for the treatment of rare/orphans and neglected diseases. }\end{array}$} \\
\hline d on: $28 / 11 / 2017$ & \\
\hline cepted on: $21 / 04 / 2018$ & \\
\hline Available online: $31 / 08 / 2018$ & \\
\hline $\begin{array}{l}\text { Key words: } \\
\text { drug repositioning, drug } \\
\text { repurposing, neglected } \\
\text { diseases, rare diseases, } \\
\text { orphans diseases. }\end{array}$ & \\
\hline
\end{tabular}

\section{INTRODUCTION}

The development of a drug is a long and complex process, with extremely high investment and small expectation of success (Kaitin, 2010; Scannell et al., 2012). Currently, it is estimated that an average of $\$ 1.4$ billion will be spent on the entire research and development (R\&D) process, in the course of 10 to 17 years, resulting in a registration dossier of up to 300 thousand pages (Lombardino and Lowe, 2004; Alex et al., 2016).

The traditional research and drug development process can be simplified into two major steps: (i) preclinical and (ii) clinical. In the first one, the basic research is developed focused mainly on the identification and optimization of molecules, determination, and validation of a specific molecular target and the knowledge of pharmacological and toxicological aspects through in vitro tests and in vivo models (Lombardino and Lowe, 2004; FDA, 2015). In this step, the main objective is to obtain

\footnotetext{
${ }^{*}$ Corresponding Author

Karen Luise Lang, Federal University of Juiz de Fora, Mailing address: Manoel Byrro, 241, ZIP 35032-620, Governador Valadares, Minas Gerais, Brazil.E-mail: karenluise@gmail.com
}

a new chemical entity (NCE) - a molecule not yet described in the literature that has an active portion capable of triggering a physiological/pharmacological action (Branch and Agranat, 2014; FDA, 2015). The second major step - the clinic, is subdivided into 4 phases. The first clinical stage is phase I, conducted in volunteers with the aim of assessing the human tolerance of the new drug candidate and measuring their safe dosage (Brunton et al., 2012). Phase II consists mainly of evaluating efficacy and safety in the treatment of a specific pathology and it is essential for the continuity of the studies. Likewise, phase III assesses toxicity and safety, however, in a larger number of patients, with a number of volunteers close to the population in which the drug is intended. Furthermore, a comparison is made between the new treatment and the existing standard treatment (Katzung et al., 2014; FDA, 2015). In phase IV, also called pharmacovigilance, the new drug is already approved. The objective of this phase is a long-term evaluation of some parameters that, most of the time, are not observed in previous phases, such as adverse reactions, side effects and drug interactions (Brunton, 2012; FDA, 2015).

Despite the high investment and great efforts employed, few molecules achieve promising results. Statistically, in a 
screening of one million potential drug candidates, only one has a profile to entry in clinical studies, still susceptible to a significant number of failures. Currently, the main developmental failure in the clinical stage occurs in phase II and phase III is associated mainly with safety and efficacy (Arrowsmith, 2011a; Arrowsmith, 2011b; Harrison, 2016).

Over the past 60 years, powerful tools have been developed that directly support the development of new drugs, such as molecular biology, biotechnology, DNA sequencing, databases of three-dimensional protein structures and combinatorial chemistry (Blundell et al., 2002; Lombardino and Lowe, 2004). However, there is a significant decline observed in the number of new drugs approved for clinical use in recent years, showing a discrepancy in the face of scientific advances and R\&D investments. In the world's largest pharmaceutical market, the North American, the number of new drugs approved by the Food and Drug Administration (FDA), despite billions of dollars spent on R\&D, falls by half every nine years (Scannell et al., 2012).

As a result, Drug Discovery programs are pursuing strategies that optimize the $R \& D$ process. Among them, we highlight the drug repositioning (DR) - an approach that seeks new therapeutic applications for already approved drugs, different from its initial indication. This strategy is intended to reduce costs and research time considerably when compared to traditional R\&D methods (Ashburn and Thor, 2004; Ekins et al., 2011).

In recent decades there has been a continuous increase in the incidence of chronic diseases, such as diabetes and hypertension, and a greater interest of the pharmaceutical companies in the development of therapies for the treatment of these diseases. Consequently, there is less investment in the development of drugs for the treatment of rare, orphan and neglected diseases because they often have a lower economic return (Robertson and Renslo, 2012; Berenstein et al., 2016). According to the World Health Organization (WHO), approximately 1 billion people are affected by neglected diseases and 420 to 560 million by rare diseases (WHO, 2017a). Some global initiatives such as the WHO special program Tropical Disease Research aims to encourage research and innovation in the development of medicines to improve the health and well-being of populations affected by neglected diseases.

This paper provides a non-exhaustive review of recent data about DR as a systematic, safe and effective strategy inside the drug R\&D process, aiming to understand concepts, methodologies, advantages, challenges and relevance in the development of new therapies for rare, orphans and neglected diseases.

\section{DRUG REPOSITIONING}

DR (or redirection) can be defined as a process of identification and discovery of new therapeutic uses, outside the scope of the original pharmacological indication, for already approved drugs. However, it is common to find difficulties in conceptualizing the DR, since it is a new term and its definition is often ambiguous and unclear (Ashburn and Thor, 2004; Li et al., 2011; Oprea and Mestres, 2012; Langedijk et al., 2015). Some definitions include drug candidates or abandoned drugs, as described by Padhy and Gupta (2011) and Allarakhia (2013) were repositioning have been the search for new therapeutic indications for existing drugs or drug candidates that did not demonstrate efficacy for their particular indication in the phase II or phase III trials, but have a known pharmacological and toxicological profile, including drugs with expiring patents.

In view of the inconsistency of terminologies found in the literature, Murteira et al. (2013) proposed a harmonized nomenclature for DR: (i) repositioning, (ii) reformulation, and (iii) combination. Repositioning is defined as the process of discovering new therapeutic indications for drugs, drugs candidates or abandoned drugs, other than the indication previously approved or intended, considering the 10th version of the International Classification of Diseases (ICD-10), except for the situations in which the new use is similar to the initial indication with different pharmacological targets. The reformulation consists in the development of new formulations for medicinal products by exploiting technological advances towards the release of active substances, pharmaceutical forms, and routes of administration. The latter approach, however, is determined as the combination of one or more drugs previously used as separate pharmaceuticals and is a strategy for recurrent drug reuse in repositioning (Murteira et al., 2013).

Although the methodology has long been known, the use of the term DR, as a strategy in R\&D for new therapies could not be found in the literature before 2004 (Langedijk et al., 2015). Nevertheless, it is possible to observe the practice of this strategy in the late 1990s, with the repositioning of thalidomide. This drug was responsible for one of the biggest tragedies of medicine in the 1960s when it was widely used as antiemetic for pregnant women. Thalidomide has a teratogenic form, and as the drug was used in the racemic mixture, the result was the birth of children with congenital deformities, being withdrawn from the market in that same decade (Vianna et al., 2017). However, Sampaio and coworkers (1991) demonstrated that thalidomide plays an essential role in the selective inhibition of tumor necrosis factor $(\mathrm{TNF}-\alpha)$, cytosine found in elevated levels in leprosy patients. FDA approved the drug for the treatment of erythema nodosum leprosum, a serious and debilitating condition associated with leprosy, in July 1998 based on these studies (Vianna et al., 2017). Thalidomide was again repositioned for the treatment of refractory multiple myeloma, the use is regulated in Brazil by The Brazilian Health Regulatory Agency (ANVISA), in 2000 (Singhal et al., 2000; Ashburn and Thor, 2004; Brazil, 2000; Brazil, 2011).

Another important example, which also occurred in the 1990s, was the repositioning of sildenafil. The drug entered clinical studies for its potential antianginal effect, but cardiovascular effects were unsatisfactory and several volunteers reported unusually strong and persistent erections during their use. Sildenafil (Viagra $\AA$ ) was approved in the following years and became a blockbuster in the treatment of erectile dysfunction (Boolell et al., 1996; Ashburn and Thor, 2004). In this case, a repositioning of a drug candidate was observed, which at the time was not classified in this way. Currently, sildenafil has been repositioned again, being used as an orphan drug in the therapy of severe pulmonary hypertension (Galiè et al., 2005; Velayati et al., 2016).

\section{ADVANTAGES AND CHALLENGES}

Repositioning has several advantages in comparison with traditional approaches to drug development. A repositioned 
drug does not need the initial six to nine years typically required for the development of new drugs, but instead goes directly to preclinical testing and clinical trials, thus reducing risk and costs. At the start of a repositioning project, a range of toxicological, pharmacological and clinical safety information is already available, as candidates have now gone through some stages of development such as structural optimization, preclinical and/or clinical trials, in addition to the possibility of the candidate being an approved drug, having its clinical safety already been attested by the time of use (Ashburn and Thor, 2004; Padhy and Gupta, 2011; Oprea and Mestres, 2012; Novac, 2013; Zheng et al., 2017).
In this way, there is a reduction of the risks associated with failures in the early stages of development, which are high in traditional approaches, as well as a significant cost reduction and a possible increase in clinical safety.

When comparing traditional drug discovery programs with others using DR, a significant reduction of the time spent in $\mathrm{R} \& \mathrm{D}$ can be observed. In traditional approaches, it is estimated that 10 to 17 years are spent for the development of a new drug, while in DR the estimated time is between 3 to 12 years (Figure 1) (Ashburn and Thor, 2004; Vora et al., 2016).

\begin{tabular}{|c|c|c|c|c|c|c|c|}
\hline $\begin{array}{c}\text { (a) } \\
\text { TRADITIONAL } \\
\text { APPROACHES TO }\end{array}$ & $\begin{array}{c}\text { TARGET } \\
\text { DISCOVERY }\end{array}$ & $\begin{array}{c}\text { DISCOVERY } \\
\& \\
\text { SCREENING }\end{array}$ & $\begin{array}{c}\text { LEAD } \\
\text { OPTIMIZATION }\end{array}$ & ADMET & EVELOPMENT & REGISTRATION & \\
\hline DRUG & $2-3$ years & $0.5-1$ years & $1-3$ years & $1-2$ years & $5-6$ years & $1-2$ years & MAR K E T \\
\hline $\begin{array}{l}10-17 \text { year process } \\
\text { Small probability of } \\
\text { success }\end{array}$ & $\begin{array}{l}\text { Expression analysis; } \\
\text { In vitro function; } \\
\text { In vivo validation; } \\
\text { Bioinformatics. }\end{array}$ & $\begin{array}{c}\text { DISCOVERY } \\
\text { Traditional } \\
\text { Combinatorial chemistry } \\
\text { Structure-based drug } \\
\text { design } \\
\text { SCREENING } \\
\text { In vitro } \\
\text { Ex vivo and in vivo } \\
\text { HTS/HCS. }\end{array}$ & $\begin{array}{l}\text { Traditional } \\
\text { medicinal } \\
\text { chemistry; } \\
\text { Rational drug } \\
\text { design. }\end{array}$ & $\begin{array}{l}\text { Bioavailability and } \\
\text { systemic exposure } \\
\text { (absorption, } \\
\text { clearance and } \\
\text { distribution). }\end{array}$ & $\begin{array}{l}\text { Must start clinical } \\
\text { testing at Phase I. }\end{array}$ & $\begin{array}{c}\text { United States (FDA) } \\
\text { Europe (EMEA) } \\
\text { Japan (MHLW) } \\
\text { Brazil (ANVISA) } \\
\text { Rest of world. }\end{array}$ & \\
\hline $\begin{array}{c}\text { (b) } \\
\text { DRUG }\end{array}$ & COMPOUND & $\begin{array}{l}\text { COMPOUND } \\
\text { ACQUISITION }\end{array}$ & DEVELOPMENT & REGISTRATION & & & \\
\hline REPOSITIONING & $1-2$ years & $0-2$ years & $1-6$ years & $1-2$ years & M A R K E T & & \\
\hline $\begin{array}{l}3-12 \text { year process } \\
\text { Reduced safety and } \\
\text { pharmacokinetic } \\
\text { uncertainty }\end{array}$ & $\begin{array}{c}\text { Targeted } \\
\text { searches } \\
\text { Novel insights } \\
\text { Specialized } \\
\text { screening } \\
\text { platforms } \\
\text { Serendipity. }\end{array}$ & $\begin{array}{c}\text { Licensing } \\
\text { Novel IP } \\
\text { Both licensing } \\
\text { and novel IP } \\
\text { Internal sources. }\end{array}$ & $\begin{array}{l}\text { May start at } \\
\text { preclinical, Phase I } \\
\text { or Phase II stages; } \\
\text { Ability to leverage } \\
\text { existing data } \\
\text { packages. }\end{array}$ & $\begin{array}{l}\text { United States (FDA) } \\
\text { Europe (EMEA) } \\
\text { Japan (MHLW) } \\
\text { Brazil (ANVISA) } \\
\text { Rest of world. }\end{array}$ & & & \\
\hline
\end{tabular}

Fig. 1: A comparison between traditional approaches versus DR for drug discovery and development Ashburn and Thor (2013), adapted.

However, the DR faces some challenges: new preclinical and/or clinical trials may be necessary if the available data are not satisfactory, outdated or do not meet the requirements of regulatory agencies such as ANVISA, FDA or the European Medicines Agency (EMA) (Ashburn and Thor, 2004; Padhy and Gupta, 2011). Another recurrent obstacle is the low potency or high toxicity of the drugs in view of the new therapeutic indications, as the known and tolerated concentrations of the drugs are lower or higher than the required therapeutic concentrations. The use of combinations of two or more drugs with different mechanisms of action is an alternative that can help the success of DR (Sun et al., 2016; Zheng et al., 2017).

The development of a new pharmaceutical is very time consuming, extremely costly and high risk. Therefore, a market exclusivity period is required to achieve a return on investment commensurate with the risks. There are basically two means to achieve market exclusivity: through patents or granted by regulatory agencies (Barratt and Frail, 2012).

Some regulatory and intellectual property/patent barriers make DR difficult. For example, in the United States, where the patent for a medicinal product is valid for up to 20 years, only the patent owners have the autonomy to change or insert any data in the leaflet, repositioning the drug while it is in force (Smith, 2011; Murteira et al., 2011). Often, potential DR is already known in the scientific literature or in clinical practice with off-label use, and even though it has not been approved by regulatory agencies, it can no longer be patented, since there has been widespread public knowledge (Ashburn and Thor, 2004; Smith, 2011; Murteira et al., 2014).

The repositioning of old drugs that do not have patent owners becomes uninteresting for pharmaceutical companies, as they do not promote significant financial returns. Registering a patent source for a repositioning that has generic drugs does not guarantee a period of exclusivity in the market, once these drugs are widely available to many manufacturers. In addition, there is the possibility of an off-label, use for an indication other than that authorized by the competent regulatory body, and skinny-label, when the applicant for generic medicine requests a marketing authorization and excludes product information relating to indications or pharmaceutical forms protected by patents (Witkowski, 2011; Barratt and Frail, 2012). 
However, there are some regulatory strategies that make DR an attractive approach to pharmaceutical companies, as patent extension and regulatory exclusivity period for the new product, protecting its new formulation, indication or methods of use, even when the original product has already lost its protection patent for the active pharmaceutical ingredient, formulation and/or indication (Smith, 2011; Witkowski, 2011; Murteira et al., 2014).

Repositioning a non-orphan drug for an orphan disease is an excellent example of attractive development, with good periods of regulatory exclusivity (7 years in the United States, 10 years in the European Union and Japan), tax credits of $50 \%$ in development costs, R\&D grants and incentives, FDA's rapid approval profile and dispensing of drug application fees. In Brazil, no information related to repositioning was found on ANVISA website and in the literature, showing the need for updating regarding the regulation of repositioning/repurposing of drugs and medicines in the country (Smith, 2011; Barratt and Frail, 2012).

Pharmaceutical companies specialized in DR often face recurring problems like the lack of specialists in the field, technology and market issues facing large pharmaceutical companies. An example of success was the repositioning of mifepristone for the treatment of hyperglycemia secondary to hypercortisolism in adult patients with endogenous Cushing's syndrome who have type 2 diabetes mellitus or glucose intolerance, by Corcept Therapeutics, which is specialized in repositioning (Fleseriu and Petersenn, 2012; Novac, 2013).

There is a political, social and economic dimension involved in DR and the discovery of new therapies. Success in the pharmaceutical market does not depend exclusively on efficient or effective therapy, but also on market factors, the intended indication of the drug and the characteristics of the target population (age, socioeconomic condition, access to pharmaceutical and medical care) that directly implicate on the final value of the new therapy. As a result, efficient repositioning does not directly mean a commercially successful drug.

\section{DR PROFILES}

The DR has two profiles: on target and off target (Figure 2). In the first one, the known pharmacological mechanism of a drug or drug candidate is applied to new therapeutic indications, i.e., they are molecules that act on the same biological target in the treatment of different diseases (Barratt and Frail, 2012; Koch et $a l ., 2014)$. One example is the repositioning of finasteride for the treatment of male pattern baldness (Vora et al., 2016). This drug was originally developed for the treatment of benign prostatic hyperplasia because its mechanism of action leads to a reduction in the bioavailability of dihydrotestosterone - a biologically active metabolite of testosterone, the hormone responsible for normal and abnormal prostate growth - by the inhibition of the 5 - $\alpha$-reductase enzyme. The bioavailability of dihydrotestosterone in the scalp is also reduced with the use of finasteride, leading to inhibition of miniaturization of the hair follicle and helping in the treatment of male pattern baldness (alopecia). In the repositioning of finasteride, an on-target profile is observed, since the drug acts on the same target and produces two different therapeutic effects (Ashburn and Thor, 2004; Vora et al., 2016; Würth et al., 2016). (a)

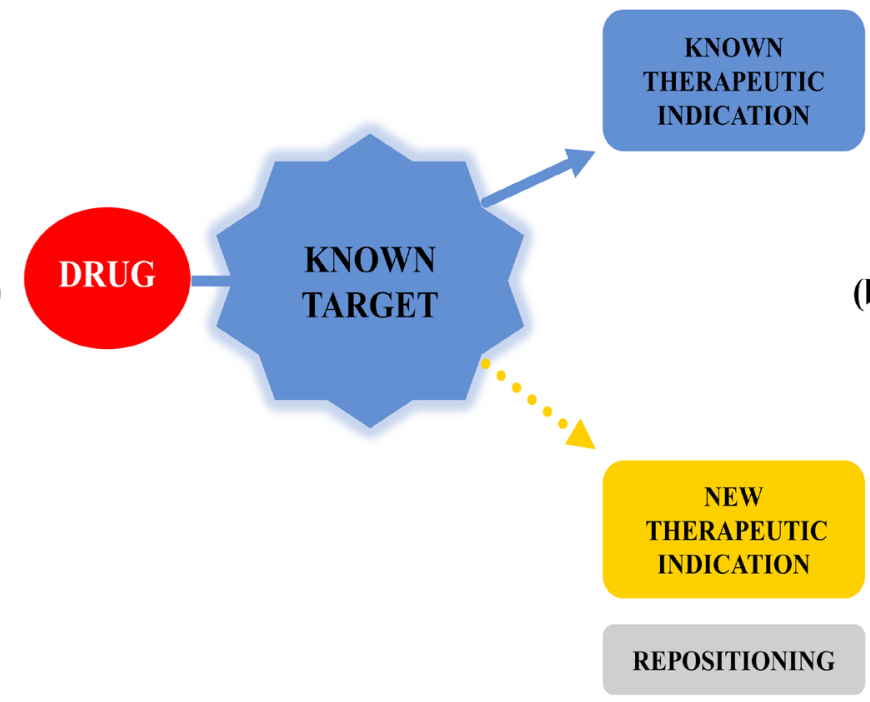

b)

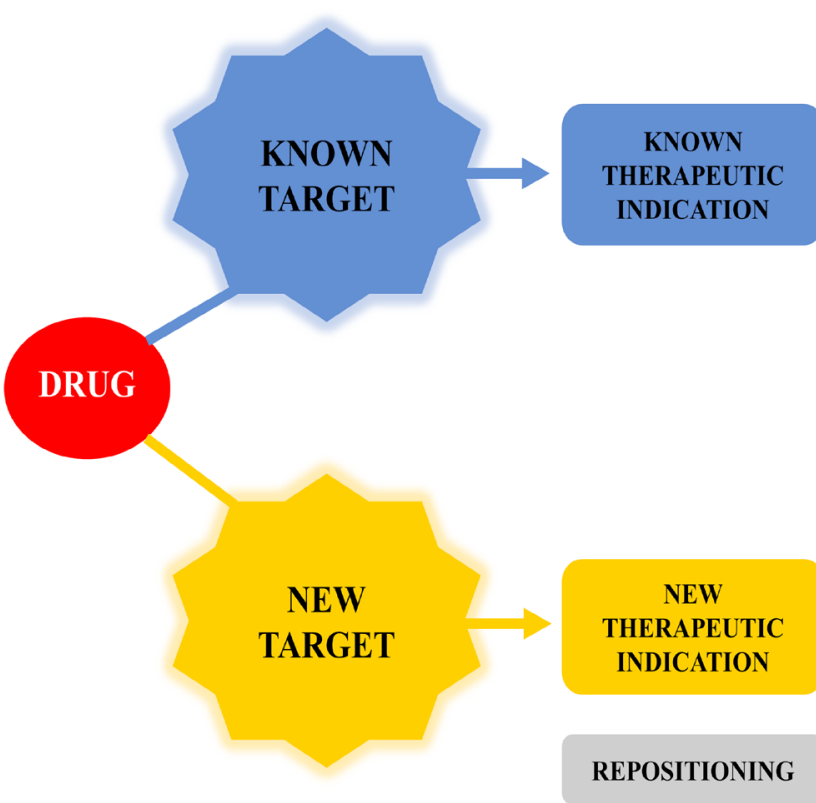

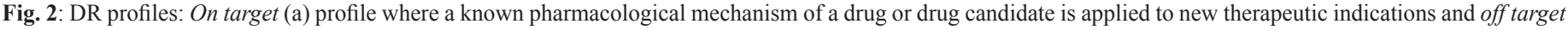
(b) profile where the pharmacological mechanism is unknown and the drugs act on new targets, out of the original scope, for new therapeutic indications.

In the off-target profile, the pharmacological mechanism is unknown. Drugs and drugs candidates act on new targets, out of the original scope, for new therapeutic indications. Therefore, both the targets and the indications are new (Koch et al., 2014; Vora et al., 2016; Würth et al., 2016). These repositioning, in the main, are discovered through the serendipity and several computational strategies using different databases, algorithms, molecular coupling, among 
others. Thalidomide, described above, is an excellent example of the off-target profile.

\section{MAIN METHODOLOGIES USED FOR REPOSITIONING}

The methodologies applied in repositioning can be divided into three groups: (i) drug-oriented, (ii) target-oriented, and (iii) disease/therapy-oriented. The type of guidance in which the methodologies are applied depends mainly on the quantity and quality of the pharmacological, toxicological and biological information (Jin and Wong, 2014).

In the drug-oriented methodologies, the structural characteristics of the molecules, off-label use data, adverse effects and phenotypic screening are evaluated (Jin and Wong, 2014). This screening is a strategy for identifying molecules with biological effects in cell/animal assays in order to identify compounds that cause some desirable change in a particular phenotype (Moffat et al., 2017). This type of guidance is based on traditional pharmacology, where little data is available and only after the discovery of activities against phenotypes studies are conducted to determine the biological targets related (Swinney, 2013; Jin and Wong, 2014; Moffat et al., 2017). The greatest DR successes to this date have been obtained with this orientation profile, through serendipity or clinical observation, such as sildenafil, previously discussed. This process can be considered a blind research approach, i.e., the discovery of new indications occurs randomly, especially during clinical R\&D trials (Ashburn and Thor, 2004).

Target-based DR methods comprise in vitro and in vivo high-throughput and/or high-content screening (HTS/ HCS) of drugs for a protein or a biomarker of interest and in silico screening of drugs or compounds from drug libraries such as ligand-based screening or docking (Kolb et al., 2009; Jin and Wong, 2014; Li et al., 2016; Bellomo et al., 2017). Compared with drug-oriented methods, targeted-based methods significantly improve the likelihood of drug discovery because most targets link directly with the disease mechanisms (Swinney, 2013; Jin and Wong, 2014).

On the other hand, if there is more disease information available, DR can be guided by diseases and/or treatments. This information is given by proteomics, genomics, metabolomics or data concerning how drugs modulate phenotypes in diseases, e.g., knowledge of adverse and side effects with possible off-target mechanisms. The main methods applied here are computational such as network and pathway analysis. They consist of construction of specific disease networks, considering key targets, identifying proteins related to cell and metabolic pathways of interest. These methods help to understand the omics data, allowing the discovery of pathways of diseases and their possible pharmacological targets (Liu et al., 2013; Li and Lu, 2013; Jin and Wong, 2014; Jadamba and Shin, 2016; Berenstein et al., 2016; Wu et al., 2017).

The DR methods based on signature genes are diseasedriven and use disease-specific genetic data with or without treatments, for the discovery of off-target mechanisms or unknown pathological mechanisms. In addition, there are methods based on chemoinformatics and bioinformatics knowledge, integrating a large amount of data available for diseases and drugs such as adverse effects, off-label use, target drug networks, drug chemical structures, omics data, among others. These methods include a large amount of known information that can improve the DR process (Dudley et al., 2011; Iorio et al., 2013; Jin and Wong, 2014; Wu et al., 2017).

It is important to highlight available free databases that provide free access to essential data in repositioning strategies for pharmaceutical companies and academic research centers. Some of these databases focus on neglected diseases, such as the TDR Targets database (http://tdrtargets.org), which explores the availability of genomic and chemical data to facilitate the identification and prioritization of drugs and targets in neglected disease pathogens (Magariños et al., 2012). Another important database is TriTrypDB (http://tritrypdb.org/tritrypdb/) which has a large amount of genomic and functional data integrated for pathogens of the Trypanosomatidae family, including organisms of the genus Leishmania and Trypanosoma, responsible for leishmaniasis and Chagas disease (Aslett et al., 2010; Silva et al., 2015; TDR, 2017; TritryBD, 2017).

The computational and systematic methodologies offer a robust and logical approach to the discovery of new indications, demonstrating a greater efficiency than the processes based on serendipity. These methodologies offer a rational and exhaustive exploration of all possible repositioning opportunities, taking into consideration improved access to high-quality data, analytical capacity and technological advances.

\section{NEGLECTED TROPICAL DISEASES}

Neglected tropical diseases (NTDs) are a diverse group of communicable diseases that prevail in tropical and subtropical conditions affecting more than one billion people. Populations living in poverty, without adequate sanitation and in close contact with infectious vectors and domestic animals and livestock are those worst affected (WHO, 2017b; Peeling et al., 2017).

Available treatments for NTDs have several limitations, such as cost, safety profile and/or efficacy poorly established and possible drug resistance mechanisms. In addition, there is a limited commercial interest in the development of drugs for the treatment of these conditions, due to the onerous nature, the associated risk and the low financial return on investments in R\&D (WHO, 2017a; Berenstein et al., 2016).

For this reason, development of therapies for these diseases becomes increasingly necessary. It reaffirms the importance of repositioning in the development of these therapies, mainly because of the advantages over traditional approaches, such as a significant reduction of costs, risks, and an improvement in safety and efficacy profiles for an area that has historically suffered from limited resources and an enormous need for effective therapies (Ashburn and Thor, 2004; Ekins et al., 2011; Berenstein et al., 2016).

There are some successful DR on DTNs. Miltefosine, repositioned for the treatment of visceral leishmaniasis was initially an antineoplastic compound, but during phase II clinical trials, the drug did not show satisfactory activity, being limited to topical treatment of cutaneous metastases (Barratt and Frail, 2012; Verhaar et al., 2014). The antileishmanial activity was described in 1987 and miltefosine was the first effective oral treatment for cutaneous and visceral leishmaniasis (Machado et al., 2010; Padhy and Gupta, 2011; Barratt and Frail, 2012).

Another important DR on DTNs was amphotericin B, a drug used for the treatment of systemic fungal infections and 
repositioned for the treatment of visceral leishmaniasis. This approval was supported directly by the Phase IV clinical safety data accumulated by the time of use of amphotericin B as an antifungal (Padhy and Gupta, 2011; Barratt and Frail, 2012).

Another repositioning can also be highlighted as antibacterial (dapsone, sulfadoxine), tetracyclines (doxycycline) and the combination of trimethoprim/sulfamethoxazole and fluoroquinolones in the treatment of malaria and tuberculosis (Nzila et al., 2011; Barratt and Frail, 2012).

Nowadays, several studies have reported promising results regarding repositioning aided by computational tools such as target-based chemogenomics screen in the development of therapies for NTDs, such as schistosomiasis (Neves et al., 2015). Other examples of a potentially promising repositioning for this disease are antineoplastic inhibitors of kinases proteins, e.g. trametinib, vandetanib - and the HMG-CoA reductase inhibitor drugs, e.g. atorvastatin (Rojo-Arreola et al., 2014; Cowan and Keiser, 2015).

Brazil is affected by several NTDs, but a current concern is with viral diseases such as dengue, Zika, and chikungunya. Zika virus, in special, is associated with severe birth defects and Guillain-Barré syndrome (Cao-Lormeau et al., 2016; MirandaFilho et al., 2016; Mlakar et al., 2016). To date, no antiviral agents have been approved for treating Zika virus infection. However, two recent drug-repurposing studies (Tabata et al., 2016; Xu et al., 2016) demonstrated that screening FDA-approved drugs for antiviral activity is a promising strategy for identifying therapeutics with novel activity against Zika virus infection. Recent works have identified promising activities of sofosbuvir (SOF), currently approved by the FDA for the treatment of hepatitis $\mathrm{C}$. This drug targets viral RNA polymerase, a common protein among Zika virus and hepatitis $\mathrm{C}$ virus (Mesci et al., 2018). It has been shown that SOF present protective activity for human neuronal progenitor cells and a reduction of viral load both in vitro and in vivo (Sacramento et al., 2017; Ferreira et al., 2017; Mesci et al., 2018). Besides, the work of Simanjuntak and co-workers (2015) evidences the promising repositioning of prochlorperazine, a dopamine $\mathrm{D} 2$ receptor antagonist approved to treat nausea, vomiting, and headache in humans that has potent in vitro and in vivo antiviral activity against dengue virus infection, by targeting viral binding and viral entry.

\section{RARE OR ORPHAN DISEASES}

There are an estimated 7000 rare diseases in the world. Considering them individually they reach a small number of people, however together they affect between $6 \%$ and $8 \%$ of worldwide population. There are many concepts for rare or orphan diseases (RD), but they have one key point in common - a group of diseases that affect a small portion of the population (Ekins et al., 2011; NIH, 2017; Orphanet, 2017).

In the United States, the Orphan Drug Act (1983) defines $\mathrm{RD}$ as any disease or condition that affects less than 200.000 people. In Japan, a disease is considered rare when affects less than 50.000 patients (Tambuyzer, 2010; Barratt and Frail, 2012; Richter et al., 2015). The European Commission on Public Health (2016) defines rare diseases as potentially fatal or chronic, mostly hereditary, affecting a small number of people, approximately 1 in 2000. In Brazil, the National Policy of Integral Attention to People with Rare Diseases ordinance was approved, considering rare those that affects up to 65 people in every 100.000 individuals (Brazil, 2014). This ordinance can be considered a milestone in the health care of patients with rare diseases in the country.

Often the concept of rare diseases is mistaken for that of neglected tropical diseases mainly by the sanitary laws of some countries, which use the term "orphan medicine" to designate treatments of a rare disease as well as the NTD. These drugs are designated as orphans because under normal market conditions, pharmaceutical companies have little interest in development and marketing due to the small number of individuals affected (Ekins et al., 2011).

The development of drugs for the treatment of rare diseases faces major challenges since the low number of individuals affected and the large geographic distribution can make clinical trials invalid or difficult. Another recurring problem is the great heterogeneity among diseases, being mostly influenced by genetic factors. Besides, there is a long period of development, high costs, and extremely low success rates, reaching a group of extremely specific and reduced patients, not bringing a financial return on investments and R\&D (Sardana et al., 2011; Augustine et al., 2013; Hee et al., 2017).

In view of this, DR is an interesting strategy, given the possible prior knowledge of safety profiles, bioavailability, tolerance in humans and some pharmaceutical and pharmacodynamic aspects, which can significantly reduce the risks associated with drug development and potentially facilitate the beginning of clinical trials, with reduced investment costs when compared to traditional approaches (Ekins et al., 2011; Barratt and Frail, 2012).

The relevance given to the repositioning of drugs in rare diseases can be observed in the incentives offered by the governmental entities of some countries for the pharmaceutical and biotechnology industries. Influencing R\&D of drugs in the treatment of these diseases, providing reductions in fees for regulatory procedures, regulatory assistance, market exclusivity, among other benefits mentioned before (Li and Jones, 2012; Murteira et al., 2014).

\section{CONCLUSION}

Repositioning is an approach that has been used for a long time, but the ability to carry it out in a systematic and rational way is an innovation that can meet social and market needs. Despite this, the greatest repositioning successes still being discovered through serendipity.

It is remarkable, however the importance and advantages of DR in the development of new therapies. This approach offers lower R\&D costs, greater chances of success, shorter research time and lower investment risk. These advantages are of benefit to patients and pharmaceutical companies, enabling the application of DR in rare and neglected diseases that have several limitations in traditional approaches. Thus DR can be a tool in the development of treatments for diseases that suffer historically from limited resources and a huge need for effective therapies.

\section{FINANCIAL SUPPORT AND SPONSORSHIP}

The authors acknowledge the financial support of Fundação de Apoio à Pesquisa do Estado de Minas Gerais, FAPEMIG (grants CDS APQ 02194/14 and CDS APQ 03606/16). 


\section{CONFLICT OF INTERESTS}

The authors declare no conflicts of interest.

\section{REFERENCES}

Alex A, Harris CJ, Smith DA. 2016. Attrition in the Pharmaceutical Industry: Reasons, Implications, and Pathways Forward. Hoboken, United States: John Wiley \& Sons.

Allarakhia M. Open-source approaches for the repurposing of existing or failed candidate drugs: learning from and applying the lessons across diseases. Drug Des Devel Ther. 2013; 7:753-766.

Arrowsmith J. Trial watch: Phase II failures: 2008-2010. Nat Rev Drug Discov. 2011a; 10(5):328-329.

Arrowsmith J. Trial watch: Phase III and submission failures: 2007-2010. Nat Rev Drug Discov. 2011b; 10(2):87.

Ashburn TT, Thor KB. Drug repositioning: identifying and developing new uses for existing drugs. Nat Rev Drug Discov. 2004; 3(8):673-683.

Aslett M, Aurrecoechea C, Berriman M, Brestelli J, Brunk BP, Carrington M, Depledge DP, Fischer S, Gajria B, Gao X, Gardner MJ, Gingle A, Grant G, Harb OS, Heiges M, Hertz-Fowler C, Houston R, Innamorato F, Iodice J, Kissinger JC, Kraemer E, Li W, Logan FJ, Miller JA, Mitra S, Myler PJ, Nayak V, Pennington C, Phan I, Pinney DF, Ramasamy G, Rogers MB, Roos DS, Ross C, Sivam D, Smith DF, Srinivasamoorthy G, Stoeckert CJ Jr, Subramanian S, Thibodeau R, Tivey A, Treatman C, Velarde G, Wang H. TriTrypDB: a functional genomic resource for the Trypanosomatidae. Nucleic Acids Res. 2010; 38:457-462.

Augustine EF, Adams HR, Mink JW. Clinical Trials in Rare Disease: Challenges and Opportunities. J Child Neurol. 2013; 28(9):11421150.

Barratt MJ, Frail DE. 2012. Drug Repositioning Bringing New Life To Shelved Assets And Existing Drugs. Hoboken, United States: John Wiley \& Sons.

Bellomo F, Medina DL, De Leo E, Panarella A, Emma F. High-content drug screening for rare diseases. J Inherit Metab Dis. 2017; 40(4):601-607.

Berenstein AJ, Magariños MP, Chernomoretz A, Agüero F. A Multilayer Network Approach for Guiding Drug Repositioning in Neglected Diseases. PLoS Negl Trop Dis. 2016; 10(1):e0004300.

Blundell TL, Jhoti H, Abell C. High-throughput crystallography for lead discovery in drug design. Nat Rev Drug Discov. 2002; 1(1):45-54.

Boolell ML, Allen MJ, Ballard SA, Gepi-Attee S, Muirhead GJ, Naylor AM, Osterloh IH, Gingell C. Sildenafil: an orally active type 5 cyclic GMP-specific phosphodiesterase inhibitor for the treatment of penile erectile dysfunction. Int J Impot Res. 1996; 8(2):47-52.

Branch SK, Agranat I. New Drug Designations for New Therapeutic Entities: New Active Substance, New Chemical Entity, New Biological Entity, New Molecular Entity. J Med Chem. 2014; 57(21):87298765 .

Brazil. 2000. Available at: http://pesquisa.in.gov.br/imprensa/ jsp/visualiza/index.jsp?data $=24 / 04 / 2000 \&$ jornal $=1$ \&pagina $=38$. $[$ Accessed 29 October 2017].

Brazil. 2011. Available at: http://bvsms.saude.gov.br/bvs/ saudelegis/anvisa/2011/res0011_21_03_2011.html. [Accessed 29 October 2017].

Brazil. 2014. Available at: http://bvsms.saude.gov.br/bvs/ saudelegis/gm/2014/prt0199_30_01_2014.html. [Accessed 10 October 2017].

Brunton LL, Chabner BA, Knollmann BC. 2012. Goodman And Gilman's The Pharmacological Basis of Therapeutics 12th edition. New York, United States: McGraw-Hill Medical.

Cao-Lormeau VM, Blake A, Mons S, Lastere S, Roche C, Vanhomwegen J, Dub T, Baudouin L, Teissier A, Larre P, Vial AL, Decam C, Choumet V, Halstead SK, Willison HJ, Musset L, Manuguerra JC, Despres P, Fournier E, Mallet HP, Musso D, Fontanet A, Neil J, Ghawché F. Guillain-Barré Syndrome outbreak caused by ZIKA virus infection in
French Polynesia. Lancet. 2016; 387(10027):1531-1539.

Cowan N, Keiser J. Repurposing of anticancer drugs: in vitro and in vivo activities against Schistosoma mansoni. Parasit Vectors. 2015; $8: 417-425$.

Dudley JT, Sirota M, Shenoy M, Pai R, Roedder S, Chiang AP, Butte AJ. Computational repositioning of the anticonvulsant topiramate for inflammatory bowel disease. Sci Transl Med. 2011; 3(96):96ra76.

Ekins S, Williams AJ, Krasowski MD, Freundlich JS. In silico repositioning of approved drugs for rare and neglected diseases. Drug Discov Today. 2011; 16(7-8):298-310.

European Commission on Public Health. Rare diseases. Available at: https://ec.europa.eu/health/rare_diseases/policy_en. [Accessed 10 October 2017].

FDA. 2015. The Drug Development Process. [Online] Available at: $\quad$ https://www.fda.gov/ForPatients/Approvals/Drugs/default.htm. [Accessed 10 August 2017].

Ferreira AC, Zaverucha-do-Valle C, Reis PA, Barbosa-Lima G, Vieira YR, Mattos M, Silva PP, Sacramento C, Castro HCFN, Campanati L, Tanuri A, Brüning K, Bozza FA, Bozza PT, Souza TML. Sofosbuvir protects Zika virus-infected mice from mortality, preventing short- and long-term sequelae. Sci Rep. 2017; 25; 7(1):9409-9417.

Fleseriu M, Petersenn S. Medical management of Cushing's disease: what is the future? Pituitary. 2012; 15(3):330-341.

Galiè N, Ghofrani HA, Torbicki A, Barst RJ, Rubin LJ, Badesch D, Fleming T, Parpia T, Burgess G, Branzi A, Grimminger F, Kurzyna M, Simonneau G; Sildenafil Use in Pulmonary Arterial Hypertension. N Engl J Med. 2005; 353(20):2148-2157.

Harrison RK. Phase II and phase III failures: 2013-2015. Nat Rev Drug Discov. 2016; 15(12):817-818.

Hee SW, Willis A, Tudur Smith C, Day S, Miller F, Madan J, Posch M, Zohar S, Stallard N. Does the low prevalence affect the sample size of interventional clinical trials of rare diseases? An analysis of data from the aggregate analysis of clinicaltrials.gov. Orphanet Journal of Rare Diseases. 2017; 12:44-63.

Iorio F, Rittman T, Ge H, Menden M, Saez-Rodriguez J. Transcriptional data: a new gateway to drug repositioning? Drug Discov Today. 2013; 18(7-8):350-357.

Jadamba E, Shin M. A Systematic Framework for Drug Repositioning from Integrated Omics and Drug Phenotype Profiles Using Pathway-Drug Network. BioMed Research International. 2016; 2016:39-55

Jin G, Wong STC. Toward better drug repositioning: prioritizing and integrating existing methods into efficient pipelines. Drug Discov Today. 2014; 19(5):637-644.

Kaitin K. Deconstructing the Drug Development Process: The New Face of Innovation. Clin Pharmacol Ther. 2010; 87(3):356-361.

Katzung BG, Trevor AJ, Masters SB. 2014. Basic and Clinical Pharmacology 12th Edition. New York: United States. McGraw-Hill Medical.

Koch U, Hamacher M, Nussbaumer P. Cheminformatics at the interface of medicinal chemistry and proteomics. Biochim Biophys Acta. 2014; 1844:156-161.

Kolb P, Ferreira RS, Irwin JJ, Shoichet BK. Docking \& Chemoinformatic Screens for New Ligands and Targets. Curr Opin Biotechnol. 2009; 20(4):429-436.

Langedijk J, Mantel-Teeuwisse AK, Slijkerman DS, Schutjens $\mathrm{MH}$. Drug repositioning and repurposing: terminology and definitions in literature. Drug Discov Today. 2015; 20(8):1027-1034.

Li H, Liu A, Zhao Z, Xu Y, Lin J, Jou D, Li C. Fragment-Based Drug Design and Drug Repositioning Using Multiple Ligand Simultaneous Docking (MLSD): Identifying Celecoxib and Template Compounds as Novel Inhibitors of Signal Transducer and Activator of Transcription 3 (STAT3) J. Med. Chem. 2011; 54(15):5592-5596.

Li J, Lu Z. Pathway-based drug repositioning using causal inference. BMC Bioinformatics. 2013; 14(116):S3.

Li J, Zheng S, Chen B, Butte AJ, Swamidass SJ, Lu Z. A survey of current trends in computational drug repositioning. Brief Bioinform. 2016; 17(1):2-12. 
Li YY, Jones SJ. Drug repositioning for personalized medicine. Genome Med. 2012; 4(3):27-40.

Liu Z, Fang H, Reagan K, Xu X, Mendrick DL, Slikker W Jr, Tong W. In silico drug repositioning: what we need to know. Drug Discov Today. 2013; 18(3-4):110-115.

Lombardino JG, Lowe JA. A guide to drug discovery: The role of the medicinal chemist in drug discovery - then and now. Nat Rev Drug Discov. 2004; 3(10):853-862.

Machado PR, Ampuero J, Guimarães LH, Villasboas L, Rocha AT, Schriefer A, Carvalho EM. Miltefosine in the Treatment of Cutaneous Leishmaniasis Caused by Leishmania braziliensis in Brazil: A Randomized and Controlled Trial. PLoS Negl Trop Dis. 2010; 4(12):e912.

Magariños MP, Carmona SJ, Crowther GJ, Ralph SA, Roos DS, Shanmugam D, Agüero F. TDR Targets: a chemogenomics resource for neglected diseases. Nucleic Acids Res. 2012; 40:1118-1127.

Mesci P, Macia A, Moore SM, Shiryaev SA, Pinto A, Huang CT, Tejwani L, Fernandes IR, Suarez NA, Kolar MJ, Montefusco S, Rosenberg SC, Herai RH, Cugola FR, Russo FB, Sheets N, Saghatelian A, Shresta S, Momper JD, Siqueira-Neto JL, Corbett KD, Beltrão-Braga PCB, Terskikh AV, Muotri AR. Blocking Zika virus vertical transmission. Sci Rep. 2018; 8(1):1218-1230.

Miranda-Filho DB, Martelli CM, Ximenes RA, Araújo TV, Rocha MA, Ramos RC, Dhalia R, França RF, Marques Júnior ET, Rodrigues LC. Initial Description of the Presumed Congenital Zika Syndrome. Am J Public Health. 2016; 106(4):598-600.

Mlakar J, Korva M, Tul N, Popović M, Poljšak-Prijatelj M, Mraz J, Kolenc M, Resman Rus K, Vesnaver Vipotnik T, Fabjan Vodušek V, Vizjak A, Pižem J, Petrovec M, Avšič Županc T. Zika Virus Associated with Microcephaly. N Engl J Med. 2016; 374(10):951-958.

Moffat JG, Vicent F, Lee JA, Eder J, Prunotto M. Opportunities and challenges in phenotypic drug discovery: an industry perspective. Nat Rev Drug Discov. 2017; 16(8):531-543.

Murteira S, Ghezaiel Z, Karray S, Lamure M. Drug reformulations and repositioning in pharmaceutical industry and its impact on market access: reassessment of nomenclature. Journal of Market Access \& Health Policy. 2013; 1:21131.

Murteira S, Millier A, Ghezaiel Z, Lamure M. Drug reformulations and repositioning in the pharmaceutical industry and their impact on market access: regulatory implications. Journal of Market Access \& Health Policy. 2014; 2:22813.

Neves BJ, Braga RC, Bezerra JCB, Cravo PVL, Andrade CH. In Silico Repositioning-Chemogenomics Strategy Identifies New Drugs with Potential Activity against Multiple Life Stages of Schistosoma mansoni. PLoS Negl Trop Dis. 2015; 9(1):e3435.

NIH. 2017. National Center for Advaninc Translational Sciences. Genetic and rare diseases information center. Available at: https:// rarediseases.info.nih.gov/diseases. [Accessed 03 October 2017].

Novac N. Challenges and opportunities of drug. Trends Pharmacol Sci. 2013; 34(5):267-272.

Nzila A, Ma Z, Chibale K. Drug repositioning in the treatment of malaria and TB. Future Med Chem. 2011; 3(11):1413:1426.

Oprea TI, Mestres J. Drug Repurposing: Far Beyond New Targets for Old Drugs. AAPS J. 2012; 14(4):759-763.

Orphanet. 2017. Available at: http://www.orpha.net/consor/cgibin/index.php?lng=EN. [Accessed 03 October 2017].

Padhy BM, Gupta YK. Drug repositioning: Re-investigating existing drugs for new therapeutic indications. J Postgrad Med. 2011; 57(2):153-60

Peeling RW, Boeras DI, Nkengasong J. Re-imagining the future of diagnosis of Neglected Tropical Diseases. Comput Struct Biotechnol J. $2017 ; 15: 271-274$.

Richter T, Nestler-Parr S, Babela R, Khan ZM, Tesoro T, Molsen E, Hughes DA. Rare Disease Terminology and Definitions-A Systematic Global Review: Report of the ISPOR Rare Disease Special Interest Group. Value Health. 2015; 18(6):906-914.

Robertson SA and Renslo AR. Drug discovery for neglected tropical diseases at the Sandler Center. Future Med Chem. 2011; 3(10):12791288.

Rojo-Arreola L, Long T, Asarnow D, Suzuki BM, Singh R, Caffrey CR. Chemical and Genetic Validation of the Statin Drug Target to Treat the Helminth Disease, Schistosomiasis. PLoS One. 2014; 9(1):e87594.

Sacramento CQ, Melo GR, Freitas CS, Rocha N, Hoelz LV, Miranda M, Fintelman-Rodrigues N, Marttorelli A, Ferreira AC, BarbosaLima G, Abrantes JL, Vieira YR, Bastos MM, Mello EV, Nunes EP, Tschoeke DA, Leomil L, Loiola EC, Trindade P, Rehen SK, Bozza FA, Bozza PT, Boechat N, Thompson FL, Filippis AM, Brüning K, Souza TM. The clinically approved antiviral drug sofosbuvir inhibits Zika virus replication. Sci. Rep. 2017; 7:40920-40930.

Sampaio EP, Sarno EN, Galilly R, Cohn ZA, Kaplan G. Thalidomide selectively inhibits tumor necrosis factor alpha production by stimulated human monocytes. J Exp Med. 1991; 173(3):699-703.

Sardana D, Zhu C, Zhang M, Gudivada RC, Yang L, Jegga AG. Drug repositioning for orphan diseases. Brief Bioinform. 2011; 12(4):346356.

Scannell JW, Blanckley A, Boldonn H, Warrington B. Diagnosing the decline in pharmaceutical R\&D efficiency. Nat Rev Drug Discov. 2012; 11(3):191-200.

Silva LA, Vinaud MC, Castro AM, Cravo PVL, Bezerra JCB. In Silico Search of Energy Metabolism Inhibitors for Alternative Leishmaniasis Treatments. Biomed Res Int. 2015; 2015:25-30.

Simanjuntak Y, Liang JJ, Lee YL, Lin YL. Repurposing of Prochlorperazine for Use Against Dengue Virus Infection. J Infect Dis. 2015; 211(3):394-404

Singhal S, Mehta J, Desikan R, Ayers D, Roberson P, Eddlemon P, Munshi N, Anaissie E, Wilson C, Dhodapkar M, Zeddis J, Barlogie B. Antitumor Activity of Thalidomide in Refractory Multiple Myeloma. N Engl J Med. 2000; 341(21):1565-1571.

Smith RB. Repositioned drugs: integrating intellectual property and regulatory strategies. Drug Discov Today. 2011; 8(3):131-137.

Sun W, Sanderson PE, Zheng W. Drug combination therapy increases successful drug repositioning. Drug Discov Today. 2016; 21:1189-1195.

Swinney DC. Phenotypic vs. Target-Based Drug Discovery for First-in-Class Medicines. Clin Pharmacol Ther. 2013; 93(4):299-301.

Tabata T, Petitt M, Puerta-Guardo H, Michlmayr D, Wang C, Fang-Hoover J, Harris E, Pereira L. Zika Virus Targets Different Primary Human Placental Cells Suggesting Two Routes for Vertical Transmission. Cell Host Microbe. 2016; 20(2):155-166.

Tambuyzer E. Rare diseases, orphan drugs and their regulation: questions and misconceptions. Nat Rev Drug Discov. 2010; 9(12):921-929.

TDR. 2017. Available at: http://tdrtargets.org. [Accessed 30 Setember 2017].

TritrypBD. 2017. Available at: http://tritrypdb.org/tritrypdb/. [Accessed 30 Setember 2017].

Velayati A, Valerio MG, Shen M, Tariq S, Lanier GM, Aronow WS. Update on pulmonary arterial hypertension pharmacotherapy. J Postgrad Med. 2016; 128(5):460-473.

Verhaar AP, Wildenberg ME, Peppelenbosch MP, Hommes DW, van den Brink GR. Repurposing Miltefosine for the Treatment of ImmuneMediated Disease? J Pharmacol Exp Ther. 2014; 350(2):189-195.

Vianna FSL, Kowalski TW, Fraga LR, Sanseverino MT, SchulerFaccini L. The impact of thalidomide use in birth defects in Brazil. Eur J Med Genet. 2017; 60(1):12-15.

Vora PK, Somani RR, Jain MH. Drug Repositioning: An Approach for Drug Discovery. Mini-Reviews in Organic Chemistry. 2016; 13(5):363-376.

WHO. World Health Organization. 2017a. Integrating neglected tropical diseases into global health and development: fourth WHO report on neglected tropical diseases. [Online] Available at: http://www.who. int/neglected_diseases/resources/9789241565448/en/. [Accessed 20 September 2017].

WHO. World Health Organization. 2017b. Available at: http:/ 
www.who.int/neglected_diseases/diseases/en/. [Accessed 15 September 2017].

Witkowski TX. Intellectual property and other legal aspects of drug repurposing. Drug Discov Today. 2011; 8(3):139-143.

Wu H, Huang J, Zhong Y, Huang Q. DrugSig: A resource for computational drug repositioning utilizing gene expression signatures. PLoS One. 2017; 12(5):e0177743.

Würth, R, Thellung S, Bajettol A, Mazzanti M, Florio T, Barbieri F. Drug-repositioning opportunities for cancer therapy: novel molecular targets for known compounds. Drug Discov Today. 2016; 21(1):190-199.

Xu M, Lee EM, Wen Z, Cheng Y, Huang WK, Qian X, Tcw J, Kouznetsova J, Ogden SC, Hammack C, Jacob F, Nguyen HN, Itkin M, Hanna C, Shinn P, Allen C, Michael SG, Simeonov A, Huang W, Christian KM, Goate A, Brennand KJ, Huang R, Xia M, Ming GL, Zheng W, Song H,
Tang H. Identification of small-molecule inhibitors of Zika virus infection and induced neural cell death via a drug repurposing screen. Nat Med. 2016; 22(10):1101-1107.

Zheng W, Sun W, Simeonov A. Drug repurposing screens and synergistic drug-combinations for infectious diseases. Br J Pharmacol. 2017; 175(2):181-191.

How to cite this article:

Oliveira EAM, Lang KL. Drug Repositioning: Concept, Classification, Methodology, and Importance in Rare/Orphans and Neglected Diseases. J App Pharm Sci, 2018; 8(08): 157-165. 